\title{
Bir Başarı Testi Geliştirme Çalışması: Hemşirelik Öğrencilerinin İntramüsküler Enjeksiyon Becerilerini Ölçme
}

A Study for Developing an Achievement Test: Measuring Intramuscular Injection Skills of Nursing Students

\author{
Arife ȘANLIALP ZEYREK ${ }^{1}$, Nevin KUZU KURBAN², Sümeyye ARSLAN ${ }^{3}$
}

\begin{abstract}
ÖZ
$\mathrm{Bu}$ araştırmanın amacı, hemşirelik öğrencilerinin intramüsküler enjeksiyon konusunda bilgi düzeylerini değerlendirmeyi sağlayacak geçerli, güvenilir bir başarı testi geliştirmektir. İntramüsküler Enjeksiyon Başarı Testi metodolojik bir çalışma olup 50 çoktan seçmeli soru hazırlanmıştır. Testin kapsam geçerliliği uzman görüşleri ile değerlendirilmiştir. Uzman önerilerine göre test maddelerinde düzeltme yapılmış ve bir madde çıarılmıştır. Test, bir devlet üniversitesinin hemşirelik bölümünde okuyan 57 öğrenciye uygulanmıştır. Verileri değerlendirmek için Statistical Package for the Social Sciences, 21,0 programı kullanılmıştır. Test maddelerinin analizinde; madde güçlük indeksi, madde ayırt edicilik indeksi ve Kuder Richardson-20 güvenirlik katsayıs1 kullanılmıștır. Madde analizleri sonucunda testten 28 soru maddesi çıkarılmıştır. İntramüsküler Enjeksiyon Başarı Testi 21 soru maddesinden oluşmuştur. Testin ortalama madde güçlüğü 0,59 ve Kuder Richardson20 güvenirlik katsayısı 0,71 olarak bulunmuştur. $\mathrm{Bu}$ çalışma sonucunda geliştirilen İntramüsküler Enjeksiyon Başarı Testi; geçerli ve güvenilir bir ölçme aracı olarak bulunmuştur.
\end{abstract}

Anahtar Kelimeler: Beceri, Enjeksiyon, Geçerlik, Güvenirlik, Hemşirelik, İntramüsküler.

\begin{abstract}
The study aims to build up a valid, reliable information test that will enable to nursing students to assess their knowledge of intramuscular injection. The Intramuscular Injection Success Test is a methodological study and 50 multiple choice test items were prepared. The validity of the test was assessed by expert opinion. According to the expert suggestions, the test items were corrected and one item was taken from the test. The test was applied to 57 students attending a nursing department of a state university. For data analysis, The Statistical Package for the Social Sciences, 21,0 program was used. In the statistical analysis, items difficulty index, items discriminate index and Kuder Richardson-20 reliability coefficient were used. In consequence of the item analyzes, 28 items were removed from the test. The Intramuscular Injection Success Test consists of 21 items. The mean strength of the test was 0,59 , the Kuder Richardson-20 reliability coefficient was 0,71. Intramuscular Injection Success Test developed as a result of this study; It was found to be a valid and reliable measurement tool.
\end{abstract}

Keywords: Skill, Injection, Validity, Reliability Nursing, Intramuscular.

\footnotetext{
* Pamukkale Üniversitesi Girişimsel Olmayan Klinik Araştırmalar Etik Kurulu”ndan (16.01.2018/2) izin alındl.

${ }^{1}$ Doktora Öğrencisi, Pamukkale Üniversitesi Sağlık Bilimleri Fakültesi Hemşirelik Esasları Ana Bilim Dalı, asanlialp@pau.edu.tr, ORCID:0000-0001-5456-7393

${ }^{2}$ Prof. Dr., Hemşirelik Esasları Ana Bilim Dalı, Pamukkale Üniversitesi Sağlık Bilimleri Fakültesi Hemşirelik Bölümü, nkuzu@pau.edu.tr, ORCID:0000-0001-8562-969X

${ }^{3}$ Dr Öğr. Üyesi., Hemșirelik Esasları Ana Bilim Dalı, Pamukkale Üniversitesi Sağlık Bilimleri Fakültesi Hemșirelik Bölümü, sumeyyea@pau.edu.tr, ORCID:0000-0001-9432-6893
} 


\section{GİRİŞ}

Hemşirelik eğitiminde öğrencilere uygulama becerilerinin öğretilmesi, geliştirilmesi ve değerlendirilmesi önemlidir. Hemşirelik öğrencilerinin, hastalara güvenli bakım sağlayabilmeleri için sağlı bakım ortamına girmeden önce seçilen hemşirelik becerilerinde yeterli olmaları gerekir. Hemşirelik öğrencilerinin öğrenmesi gereken önemli ve gerçekleştirilmesi zor becerilerden biri, ilaçları hastaya doğru bir şekilde uygulama becerisidir. ${ }^{1}$

İlaçları uygulama becerisi karmaşı bir beceridir. $\mathrm{Bu}$ becerinin lisans hemşireliği müfredatında, öğrencilere yeterince geliştirilemeyeceği endişesi ifade edilmektedir. $^{2}$ Öğrencilerin ilaçları uygulama becerisine sahip olabilmesi için, farmakoloji bilgisini, ilaç yönetiminin 'altı doğru ilkesini' bilmesi ve klinik karar verebilme becerisine sahip olması gerekir. ${ }^{1}$ Ülkemizde yapılan bir çalışmada hemşirelerin uygulamalarda karşılaştıkları mesleki hatalar içerisinde birinci sırada ilaç uygulama hatalarının olduğu bildirilmektedir. ${ }^{3}$

İntramüsküler (IM) enjeksiyon uygulaması ilaç uygulamalarının önemli bir parçası olup hemşirelerin sorumluluğundadır. ${ }^{4} \mathrm{Bu}$ beceri, dikkatli ve doğru bir yöntemle yapılmazsa apse, selülit, doku nekrozu, granülom, kas fibrozu, kontraktür, intravasküler enjeksiyon, hematom ve siyatik sinir hasarı gibi ciddi komplikasyonlara neden olabilir. ${ }^{5-7}$ Siyatik sinir yaralanması sonucu minör motor ve duyu anormalliklerinden, tam paraliziye kadar değişen derecelerde hasar oluşabilir ${ }^{8}$. İntramüsküler enjeksiyon uygulama işlemi cerrahi yönteme uymayı, uygulama yöntemini bilmeyi ve ilgili psikomotor beceriye sahip olmayı gerektirmektedir. ${ }^{9}$ Yapılan çalışmalarda hemşirelerin ventrogluteal alana intramüsküler enjeksiyon için gerekli bilgi ve becerilere sahip olmadikları belirtilmektedir. ${ }^{8,10-14} \mathrm{Bu}$ temel beceriyi hemşirelik öğrencilerinin klinik uygulamaya geçmeden önce kazanması gerekmektedir.

Hemşirelik eğitiminde öğrencilerin intramüsküler enjeksiyon ile ilgili öğrenme düzeylerinin uygun değerlendirme yöntemleri ile belirlenmesi, bu beceriye ilişkin bilgilerin değerlendirilmesinde objektif, güvenilir ve geçerli ölçme araçlarının geliştirilmesi gerekir. $\mathrm{Bu}$ araçlardan birisi çoktan seçmeli sorulardır. $\mathrm{Bu}$ tip sorularda maddelerinin yazımı önem kazanmaktadır. Başarı testi geliştirme çalışmaları eğitim bilimleri alanında yaygın olmasına rağmen sağlı bilimlerinde sınırlıdır. ${ }^{15-19}$ Sağlık bilimleri alanında belirlenen hedef ve davranışları gerçekleștirme düzeylerini belirlemek amacıyla standart ölçme araçlarına ihtiyaç duyulmaktadır. $\mathrm{Bu}$ çalışmanın hemşirelik ölçme değerlendirme alanına katkı sağlayacağı düşünülmektedir.

$\mathrm{Bu}$ çalışmanın amacı test geliştirme basamaklarını dikkate alarak hemşirelik ögrencilerinin intramüsküler enjeksiyon konusunda öğrenme düzeyini belirleyebilecek geçerli, güvenilir bir bilgi testi geliştirmektir.

\section{MATERYAL VE METOT}

\section{Araştırmanın Tipi}

Araştırmada metodolojik yöntem kullanıld1.

\section{Araştırmanın Yapıldığı Yer}

Araștırma; Pamukkale Üniversitesi Sağlık Bilimleri Fakültesi Hemşirelik Bölümünde gerçekleştirildi.

\section{Araștırmanın Evren ve Örneklemi}

Araştırmanın evrenini Sağlık Bilimleri Fakültesinin Hemșirelik bölümünde yer alan 2.sınıf hemşirelik öğrencileri oluşturdu. Örneklemi 2017-2018 eğitim öğretim y1lında eğitim gören, araştırmaya katılmaya gönüllü olan, hemşirelik esasları dersini almış, araştırma tarihlerinde derse aktif katılan, 
ikinci sınıf 57 hemşirelik öğrencisi oluşturmaktadir.

\section{Veri Toplama Aracının Geliştirilmesi ve Analizi}

Veri toplama aracını, araştırmacılar ilgili literatür doğrultusunda geliştirdi. ${ }^{9,20-21}$ İntramüsküler enjeksiyon başarı testi, öğrencilerin intramüsküler enjeksiyonla ilgili bilgi düzeylerini belirlemek amaciyla hazırlanmış bir başarı testidir.

Çalışmanın ilk aşamasında öğrencilerin değerlendirmeye tabi tutulacağ 1 hedef davranışlar belirlendi. Hedef davranışlar belirlenirken; intramüsküler enjeksiyon becerisine ilişkin öğrencilerin kazanmaları beklenen davranışlar dikkate alındı. Hedef davranışlarla ilgili bilgi düzeylerini belirlemek için, çoktan seçmeli soru türü kullanıldı. Çoktan seçmeli soruların avantajları şu şekilde sıralanabilir; aynı anda çok sayıda kişiye uygulanabilmesi, farklı öğrenim düzeyindeki kişilere uygulanabilmesi, kapsam geçerliğinin yüksek olması, cevaplama süresinin kısa olması, puan verme bakımından az zaman alması ve puanlama açısından yanlılığı ortadan kaldirmasıdır. $^{22}$ Ön uygulamada intramüsküler enjeksiyon becerisine ilişkin hedef davranışları kapsayacak şekilde 50 çoktan seçmeli soru maddesi hazırlandı. Bu beceride ölçülmesi amaçlanan hedef davranışlar ve bu davranışları ölçmeye yönelik hazırlanan ön uygulama soru sayısı Tablo 1'de verildi.

\section{Hazırlanan Soruların Kapsam Geçerliliğinin Değerlendirilmesi}

Geçerlilik, bir ölçme aracının ya da yönteminin ölçülmek istenen özelliği başka bir özellikle karıştırmadan, doğru bir şekilde ölçme şeklinde tanımlanır. ${ }^{23}$ Kapsam geçerliliği, bir testin bu testle ölçülmek istenen davranışları ne derece kapsadığıyla ilgilidir. Kapsam geçerliliği belirlenirken en çok kullanılan yöntem uzman kişilerin görüşlerine başvurmaktır. ${ }^{24}$

İntramüsküler enjeksiyon başarı testinde 50 soru maddesi hazırlandiktan sonra, her bir soru maddesinin ölçülmek istenen beceriyi ölçmede tutarlı olup olmadığı (geçerliliği), yazım, noktalama açısından doğru olup olmadığı, yazım dilinin ifade bakımından anlaşılırlığ 1 yönlerinden üç farklı uzmanın görüşüne başvuruldu.

Hemşirelik esasları alanındaki uzmanların görüşleri sonrası aşağıdaki düzeltmeler yapild1:

- Soru kökü ve seçeneklerdeki anlaşılmaz olan ifadeler düzeltildi.

- Sorulardan biri bilgi testi kapsamina uygun olmadığ1 görüşüyle testten çıkarıldı.

- Uzman görüşleri sonrası çoktan seçmeli soru maddesi 49'a indirildi.

\section{Bilgi Testinin Uygulaması}

Araştırmacılar tarafından hazırlanan başarı testi hemşirelik esasları dersini almış, araştırma tarihlerinde derse aktif katılan, ikinci sınıf 57 hemşirelik öğrencisine uygulandı. Öğrencilere çalışmanın amacı ve önemi açıklandıktan sonra sözel olarak onamları alındı. Uygulama sirasında öğrencilere 80 dakika süre verildi.

\section{Verilerin Analizi}

Çoktan seçmeli soru maddeleri 5 seçeneğe sahiptir. Doğru verilen cevaplara ' 1 ', yanlış ve boş olan cevaplara ise ' 0 ' puan verildi. Toplam 49 puan üzerinden değerlendirme yapıld. Veri analizi, Statistical Package for the Social Sciences (SPSS) 21.0 programı ile yapıldı. Psikometrik analizleri için madde güçlük indeksi, madde ayırt edicilik indeksi, Kuder Richardson-20 (KR-20) güvenirlik katsayısı kullanıldı.

\section{Araştırmanın Etik Yönü}

$\mathrm{Bu}$ çalışma doktora tezinin bir aşaması olarak düzenlendi ve ilgili üniversitenin Girişimsel Olmayan Etik Kurulundan (16.01.2018/2) izin alınd1. Ayrıca uygulamayı yapabilmek için Pamukkale Üniversitesi Sağl1k Bilimleri Fakültesinden kurum izni (25.01.2018/E-6298) alınd1. Başarı testi araştırmacı tarafından hazırlanmış olup izin gereksinimi yoktur. 
Tablo 1. İntramüsküler Enjeksiyon Becerisinde Ölçülmesi Amaçlanan Hedef Davranışlar ve Ön Uygulama Soru Sayılarının Dağılımı

\begin{tabular}{|c|c|c|}
\hline Konu Başlığı & Hedef Davranışlar & $\begin{array}{l}\text { Ön Uygulama } \\
\text { Soru Sayısı }\end{array}$ \\
\hline Genel bilgi/Tanımlar & $\begin{array}{l}\text { - IM* enjeksiyon ile ilgili anatomik yapıyı } \\
\text { tanımlama } \\
\text { - IM enjeksiyon ilaç uygulama bölgeleri ve } \\
\text { yaşa göre ilaç dozlarını açıklama }\end{array}$ & 2 \\
\hline $\begin{array}{l}\text { İntramüsküler enjeksiyon } \\
\text { uygulama bölgeleri }\end{array}$ & $\begin{array}{l}\text { - IM enjeksiyon uygulanacak bölgeleri } \\
\text { tanımlama } \\
\text { - IM enjeksiyon uygulanacak bölgelerdeki kas } \\
\text { ve kas gruplarını tanımlama } \\
\text { - IM enjeksiyon uygulanacak bölgeyi doğru } \\
\text { belirleme } \\
\text { - IM enjeksiyon uygulanacak bölgedeki kasın } \\
\text { uygun olup olmadığını değerlendirme } \\
\text { - IM enjeksiyon bölgelerinin avantaj ve } \\
\text { dezavantajlarını açıklama } \\
\text { - IM enjeksiyon ilaç uygulama bölgelerine } \\
\text { göre iğne uzunluğunu seçme } \\
\end{array}$ & 2 \\
\hline $\begin{array}{l}\text { İntramüsküler yoldan ilaç } \\
\text { uygulama ile ilişkili } \\
\text { komplikasyonlar }\end{array}$ & $\begin{array}{l}\text { - IM enjeksiyon sırasında ve sonrasında } \\
\text { gelişebilecek komplikasyonları açılama }\end{array}$ & 5 \\
\hline $\begin{array}{l}\text { İntramüsküler enjeksiyon } \\
\text { uygulama işlemi }\end{array}$ & $\begin{array}{l}\text { - IM enjeksiyon için temel ilkeleri tanımlama } \\
\text { - IM enjeksiyon uygulama işlem } \\
\text { basamaklarının gerekçelerini açıklama } \\
\text { - IM enjeksiyonda kullanılan hava kilidi } \\
\text { tekniğini tanımlama } \\
\text { - IM enjeksiyonda kullanılan Z tekniğinde } \\
\text { enjeksiyon uygulama basamaklarını } \\
\text { tanımlama }\end{array}$ & $\begin{array}{l}7 \\
9\end{array}$ \\
\hline Değerlendirme & $\begin{array}{l}\text { - Beklenmeyen sonuçlarla karşılaştığında } \\
\text { uygun karar verebilme }\end{array}$ & 2 \\
\hline
\end{tabular}

\section{BULGULAR VE TARTIŞMA}

İntramüsküler enjeksiyon başarı testinin güvenirlik ve geçerlilik çalışmaları yapılırken uzman görüşü sonrası kalan 49 soru maddesinde madde ayırt edicilik ve madde güçlük indeksi hesaplandı. Bu hesaplamalar sonrası nihai teste alınacak soru maddeleri belirlendi.

\section{Madde Güçlük İndeksi}

Bir testteki her bir soru maddesini doğru cevaplayan öğrenci sayısının yüzdesi madde güçlük indeksi (p) değerini verir. Bu yüzde, doğru cevaplayan öğrenci sayısının, toplam öğrenci sayısına bölümüyle elde edilir. Hesaplanan değer 0,00 ile 1,00 arasında yer alır. ${ }^{22}$ Bir soruyu öğrencilerin çoğunluğu doğru cevap vermişse sorunun sayısal değeri 1'e yaklaşır, bu değer o sorunun kolay bir soru olduğunu düşündürür. Bir soru maddesi az kişi tarafından doğru cevaplandığında, o soru maddesinin sayisal değeri 0'a doğru yaklaşır ve bu sorunun zor bir soru olduğu söylenebilir. ${ }^{23}$

Başarı testinde kullanılan 49 soru maddesinin her biri için bulunan madde güçlük indeksi değerleri Tablo 2'de gösterildi.

Nihai teste alınacak test maddelerin madde güçlük indekslerinin hangi düzeyde olması gerektiği kararı testin amacına göre değişir ${ }^{24}$. Tablo 2 incelendiğinde soruların madde güçlük dereceleri 0,10-0,94 arasında değiștiği görülmektedir.

Başarı testlerinde testin ortalama güçlügünün 0,50 civarında bir değer olması istenir. $^{22,25}$ Ancak iyi bir başarı testinde 
güçlük derecesinin yanı sıra doğru cevabı bilen ve bilmeyen öğrenciyi ayırt edebilmesi, ayrıca başarı testinin intramüsküler enjeksiyon ile ilgili beklenen hedef ve davranışlara da ulaşması istendiğinden, 'p' değeri 0,5 'ten uzak olan bazı soru maddelerinin de nihai başarı testine alınmasına karar verildi.Bir başarı testi oluşturulurken madde güçlük indeks (p) değerlerinin hesaplanması yeterli değildir bunun yanı sira madde ayırt edicilik indeks $\left(\mathrm{r}_{\mathrm{j}}\right)$ değerlerinin de hesaplanması gerekmektedir. Madde ayırt edicilik indeksi maddenin teste alınıp alınmaması konusunda karar verilmesinde önemli bir madde istatistiğidir. $^{24}$

\section{Madde Ayırt Edicilik İndeksi}

Madde ayırt edicilik indeksi (rjx), doğru cevabı bilen ve bilmeyen kişiyi ayırt etme yüzdesidir. Alabileceği değerler $-1,00$ ile 1,00 arasındadır. Öğrencilerden elde edilen veriler doğrultusunda alt ve üst olmak üzere iki grup oluşturuldu. $\mathrm{Bu}$ kategorileri oluşturmak için veriler Microsoft Excel programına aktarıldı. Her öğrencinin aldığı toplam puan hesaplandiktan sonra test puanlarına göre en yüksek puandan en düşüğüne doğru siralandı. Öğrencilerin puanlamaları yapıldıktan sonra, \%27'lik $(\mathrm{n}=16)$ alt-üst gruplar oluşturuldu. ${ }^{23}$ Aşağıdaki formüle göre intramüsküler enjeksiyon başarı testindeki soru maddelerinin ayırt edicilik indeksi hesapland1.

$$
\begin{aligned}
& r_{\mathrm{jx}}=(\mathrm{Dü}-\mathrm{Da}) / \mathrm{N} \\
& \mathrm{r}_{\mathrm{jx}}: \text { Madde ayırt edicilik indeksi }
\end{aligned}
$$

Dü: Bir soru maddesine üst grupta doğru cevap veren birey sayıs1

Da: Bir soru maddesine alt grupta doğru cevap veren birey sayıs

\section{N: Üst veya alt gruptaki birey sayıs1}

Başarı testinde kullanılan 49 soru maddesinin her biri için bulunan madde ayırt edicilik indeks $\left(\mathrm{r}_{\mathrm{jx}}\right)$ değerleri Tablo 2 'de verildi.
Tablo 2. İntramüsküler Enjeksiyon Başarı Testinde Yer Alan Soru Maddelerinin Madde Güçlük İndeksi (p), Madde Ayırt Edicilik İndeksi

\begin{tabular}{|c|c|c|}
\hline Soru Madde No & $\begin{array}{l}\text { Madde Güçlük } \\
\text { İndeksi (p) }\end{array}$ & $\begin{array}{l}\text { Madde Ayırt } \\
\text { Edicilik } \\
\text { İndeksi }\left(\mathbf{r}_{\mathbf{j}}\right)\end{array}$ \\
\hline 1 & 0,91 & 0,25 \\
\hline $2 *$ & 0,56 & 0,68 \\
\hline 3 & 0,94 & 0,00 \\
\hline 4 & 0,89 & 0,18 \\
\hline $5^{*}$ & 0,70 & 0,43 \\
\hline 6 & 0,94 & 0,00 \\
\hline $7 *$ & 0,36 & 0,37 \\
\hline $8^{*}$ & 0,59 & 0,50 \\
\hline 9 & 0,47 & 0,18 \\
\hline $10^{*}$ & 0,70 & 0,25 \\
\hline $11^{*}$ & 0,49 & 0,25 \\
\hline $12^{*}$ & 0,82 & 0,50 \\
\hline 13 & 0,71 & $-0,12$ \\
\hline 14 & 0,33 & 0,12 \\
\hline $15^{*}$ & 0,38 & 0,31 \\
\hline 16 & 0,59 & 0,12 \\
\hline 17 & 0,17 & 0,12 \\
\hline 18 & 0,54 & 0,12 \\
\hline 19* & 0,61 & 0,31 \\
\hline 20 & 0,21 & 0,06 \\
\hline $21^{*}$ & 0,73 & 0,43 \\
\hline $22^{*}$ & 0,59 & 0,43 \\
\hline $23^{*}$ & 0,52 & 0,25 \\
\hline 24* & 0,73 & 0,50 \\
\hline $25^{*}$ & 0,64 & 0,25 \\
\hline $26^{*}$ & 0,82 & 0,43 \\
\hline $27^{*}$ & 0,68 & 0,37 \\
\hline 28 & 0,56 & 0,00 \\
\hline 29 & 0,84 & 0,18 \\
\hline 30 & 0,10 & 0,12 \\
\hline 31 & 0,89 & 0,31 \\
\hline 32 & 0,85 & 0,25 \\
\hline 33 & 0,87 & 0,18 \\
\hline 34 & 0,54 & 0,00 \\
\hline 35 & 0,82 & 0,12 \\
\hline 36 & 0,85 & 0,25 \\
\hline 37 & 0,91 & 0,06 \\
\hline 38 & 0,84 & 0,18 \\
\hline $39 *$ & 0,31 & 0,31 \\
\hline $40^{*}$ & 0,47 & 0,37 \\
\hline 41 & 0,36 & 0,00 \\
\hline 42 & 0,49 & 0,18 \\
\hline 43* & 0,75 & 0,50 \\
\hline 44 & 0,36 & 0,12 \\
\hline $45^{*}$ & 0,42 & 0,31 \\
\hline $46^{*}$ & 0,50 & 0,37 \\
\hline 47 & 0,49 & 0,18 \\
\hline 48 & 0,87 & 0,12 \\
\hline 49 & 0,15 & 0,00 \\
\hline
\end{tabular}
$\left(\mathbf{r}_{\mathbf{j} \mathbf{x}}\right)$ 


\section{Nihai Teste Alınan Sorular ve Test}

Madde ayırt edicilik indeksinden negatif değer alması, o soru maddesinin testten düşük puan alan öğrenciler tarafindan doğru cevapladığını gösterir. Soru maddesinin sıfira yakın bir değer alması; puanı yüksek ve düşük olan eşit sayıda öğrencinin o soruya doğru cevap verdiğini, pozitif bir değer alması ise o soruya yüksek puan alan öğrenciler tarafından doğru cevap verildiği gösterir. Bundan dolayı ayırt edicilik indeksinde negatif ve sıfir civarında değer alan soru maddelerinin testte kullanılmaması gerektiği belirtilmiştir. ${ }^{22}$ Literatürde soru maddelerinin $\mathrm{rjx} \geq 0,25$ olduğu durumlarda; bilen ve bilmeyen öğrenciyi ayırt etmede başarılı olduğu belirtilmektedir. ${ }^{26}$

Çalışmamızda; madde ayırt edicilik indeks değeri negatif ve 0,15 arasında yer alan 17 , 0,16-0,19 arasindaki 7 soru maddesi testten çıkarıldı. Başarı testinde madde ayırt edicilik indeksleri $0,20-0,30$ arasinda yer alan 7 madde, 0,31-0,40 arasinda yer alan 9 madde, 0,41 ve üstünde değer alan 9 soru maddesi; bir değişiklik yapılmaksızın başarı testine alındı (Tablo 3).

Tablo 3. İntramüsküler Enjeksiyon Başarı Testinde Bulunan Soru Maddelerinin Madde Ayırt Edicilik İndeks Aralığına Göre Yorumları ve Madde Sayısı

\begin{tabular}{rlr}
\hline $\begin{array}{l}\text { Madde Ayırt } \\
\text { Edicilik İndeks } \\
\text { Aralığı }\end{array}$ & $\begin{array}{r}\text { Yadde } \\
\text { Sayısı }\end{array}$ \\
\hline Negatif ve 0,15 & Çıkarılmalıdır & 17 \\
$\mathbf{0 , 1 6 - 0 , 1 9}$ & Düzeltilebilir & 7 \\
$\mathbf{0 , 2 0 - 0 , 3 0}$ & Kullanılabilir & 7 \\
$\mathbf{0 , 3 1 - 0 , 4 0}$ & İyi & 9 \\
$\mathbf{0 , 4 1}$ ve üstü & Çok iyi & 9 \\
\hline
\end{tabular}

Kalan 25 soru maddesinin güçlük indeksi 0,84 'ün üstünde olan 4 soru maddesi başarı testinden çıkarıldı (Tablo 2).

\section{İstatistikleri}

Madde ayırt edicilik indeksi $\left(\mathrm{r}_{\mathrm{jx}}\right)$ ve Madde güçlük indeksi (p) değerleri incelendiğinde $2,5,7,8,10,11,12,15,19$, $21,22,23,24,25,26,27,39,40,43,45$ ve 46 numaralı soru maddelerinin intramüsküler enjeksiyon konusuna ilişkin hedef ve davranışları karşılaması ve ' $\mathrm{r}_{\mathrm{jx}}$ ' değerleri 0,25 'ten büyük olduğu için doğrudan nihai başarı testine alındı (Tablo 2).

\section{Nihai Testin Ortalama Güçlüğü}

Testin ortalama güçlüğü madde güçlük indeks toplamının soru sayısına bölümü ile bulunur. Çalışmamızda 21 soru maddesinden oluşan nihai testin ortalama madde güçlüğü $\overline{\mathrm{p}}=12,37 / 21=0,59$ olarak hesapland 1 (Tablo $4)$.

Bir testteki her soru maddesinin güçlük değeri farklı olsa da bunların ortalaması alınarak testin ortalama güçlülüğü bulunabilir. Testin ortalama güçlülügüünün 0,50 civarında bir değerde olması istenir. ${ }^{26}$ $\mathrm{Bu}$ durumda nihai testin, başarı testleri için istenilen ortalama güçlük düzeyinde olduğunu göstermektedir.

\section{Test Puanlarının Standart Sapma ve Varyansı}

Test puanlarının standart sapmasinı hesaplamak için madde güvenirlik katsayıları toplanir.

$$
\mathrm{S}_{\mathrm{x}}=3,77 \text { (Tablo 4) }
$$

Test puanlarının varyansı, test puanlarının standart sapmasının karesine eşittir.

$$
\mathrm{S}_{\mathrm{x}}{ }^{2}=3,77=14,21
$$


Tablo 4. Nihai Teste Seçilen Soru Maddelerin İstatistikleri

\begin{tabular}{|c|c|c|c|c|c|c|}
\hline $\begin{array}{l}\text { Deneme } \\
\text { Testi }\end{array}$ & Nihai Test & $\begin{array}{l}\text { Madde } \\
\text { Güçlük } \\
\text { Índeksi (p) }\end{array}$ & $\begin{array}{l}\text { Madde } \\
\text { Varyansı } \\
\left(\mathbf{s j}^{2}\right)\end{array}$ & $\begin{array}{l}\text { Madde } \\
\text { Standart } \\
\text { Sapması }\left(\mathbf{s}_{j}\right)\end{array}$ & $\begin{array}{l}\text { Madde } \\
\text { Ayırt } \\
\text { Edicilik } \\
\left.\text { İndeksi ( } \mathbf{r}_{\mathrm{j} x}\right) \\
\end{array}$ & $\begin{array}{l}\text { Madde } \\
\text { Güvenirlik } \\
\text { Katsayısı } \\
\left(\mathrm{r}_{\mathrm{j}}\right) \\
\end{array}$ \\
\hline $\begin{array}{l}\text { Madde } \\
\text { no }\end{array}$ & Madde no & $\mathbf{p}$ & $\mathrm{sj}^{2}=p \cdot q$ & $S_{j}=\sqrt{p \cdot q}$ & $\mathbf{r}_{\mathbf{j x}}$ & $\mathbf{r}_{\mathbf{j}}=\mathbf{r}_{\mathbf{j x} .} . \mathbf{S}_{\mathbf{j}}$ \\
\hline 2 & 1 & 0,56 & 0,24 & 0,49 & 0,68 & 0,33 \\
\hline 5 & 2 & 0,70 & 0,21 & 0,45 & 0,43 & 0,19 \\
\hline 7 & 3 & 0,36 & 0,23 & 0,48 & 0,37 & 0,18 \\
\hline 8 & 4 & 0,59 & 0,24 & 0,49 & 0,50 & 0,25 \\
\hline 10 & 5 & 0,70 & 0,21 & 0,45 & 0,25 & 0,11 \\
\hline 11 & 6 & 0,49 & 0,24 & 0,49 & 0,25 & 0,12 \\
\hline 12 & 7 & 0,82 & 0,15 & 0,38 & 0,50 & 0,19 \\
\hline 15 & 8 & 0,38 & 0,24 & 0,49 & 0,31 & 0,15 \\
\hline 19 & 9 & 0,61 & 0,24 & 0,49 & 0,31 & 0,15 \\
\hline 21 & 10 & 0,73 & 0,19 & 0,43 & 0,43 & 0,18 \\
\hline 22 & 11 & 0,59 & 0,24 & 0,49 & 0,43 & 0,21 \\
\hline 23 & 12 & 0,52 & 0,25 & 0,50 & 0,25 & 0,13 \\
\hline 24 & 13 & 0,73 & 0,19 & 0,43 & 0,50 & 0,22 \\
\hline 25 & 14 & 0,64 & 0,23 & 0,48 & 0,25 & 0,12 \\
\hline 26 & 15 & 0,82 & 0,15 & 0,38 & 0,43 & 0,16 \\
\hline 27 & 16 & 0,68 & 0,22 & 0,46 & 0,37 & 0,17 \\
\hline 39 & 17 & 0,31 & 0,21 & 0,45 & 0,31 & 0,17 \\
\hline 40 & 18 & 0,47 & 0,25 & 0,50 & 0,37 & 0,19 \\
\hline 43 & 19 & 0,75 & 0,18 & 0,42 & 0,50 & 0,21 \\
\hline 45 & 20 & 0,42 & 0,24 & 0,49 & 0,31 & 0,15 \\
\hline 46 & 21 & 0,50 & 0,25 & 0,50 & 0,37 & 0,19 \\
\hline TOPLAM & & 12,37 & 4,60 & 9,74 & 8,12 & 3,77 \\
\hline
\end{tabular}

\section{Kuder Richardson-20 (KR-20) Güvenirlik Katsayısı}

İki seçenekli kodlanan testlerde (yanlış cevaplar için ' 0 ', doğru cevaplar için ' 1 ' değeri kodlanır) Cronbach alfa ve KR-20 katsayılarının birbirine eşit olduğu belirtilmektedir. ${ }^{27-28} \mathrm{Bu}$ çalışmamızda KR-20 katsayısı hesapland1. İntramüsküler enjeksiyon başarı testinin iç tutarlılığını hesaplamak için aşağıdaki formül kullanılarak KR-20 değeri aşağıdaki formül ile hesapland.

$\mathrm{KR}-20=\mathrm{K} /(\mathrm{K}-1) \cdot\left[1-\left(\sum \mathrm{p} \cdot \mathrm{q}\right) / \mathrm{S}_{\mathrm{x}}{ }^{2}\right]$

$\mathrm{K}=$ Testeki soru maddesi sayıs

$\mathrm{p}=$ Madde güçlüğü

$\mathrm{q}=1-\mathrm{p}$

$\mathrm{S}_{\mathrm{x}}{ }^{2}=$ Test varyans 1

$\mathrm{Bu}$ formüle göre;

KR-20 = 21/(21-1).[1-4,6/14,21] $=0,71$
Araştırmalarda kullanılacak ölçme araçlarının güvenirlik düzeyinin alt sınırı 0,70'dir. Çalışmamızda elde edilen 0,71 değeri intramüsküler enjeksiyon başarı testinin; geçerli ve güvenilir olduğunu göstermektedir. $^{23,29}$

Geliştirilen İntramüsküler Enjeksiyon Uygulaması Başarı Testinden Örnek Sorular

1. Aşağıda intramüsküler (IM) enjeksiyon ile ilgili verilen bilgilerden yanlış olanı işaretleyiniz.

a)İntramüsküler enjeksiyonlar yenidoğanlarda vastus lateralis kasına uygulanmalıdır.

b)Ventrogluteal bölge yetişkinlerde en güvenli IM ilaç uygulama yeridir.

c)İntramüsküler enjeksiyonlarda iğnenin dokuya giriş açısı bütün bölgelerde $90^{\circ}$ "dir.

d)Rektus femoris kasina uygulanan enjeksiyonlarda siyatik sinir zedelenme riski vardir. 
e)Deltoid kası altı yaşından küçüklerde kullanılmamalıdır.

2.Aşağıdaki kas/bölgelerden hangisi intramüsküler enjeksiyon uygulaması için önerilmemektedir?

a) Dorsogluteal bölge

b) Ventrogluteal bölge

c) Deltoid kas1

d) Vastus lateralis kas1

e) Rectus femoris kas1

3.Aşağıdakilerden hangisi intramüsküler yoldan ilaç uygulama ile ilişkili gelişebilecek komplikasyonlardan biri değildir?

a) Sinir yaralanmas 1

b) Kemik yaralanmas 1

c) Tromboflebit

d) Kas veya kemik enfeksiyonu

e) Steril apse

4. İntramüsküler enjeksiyonlarla ilgili olarak aşağıda verilen ifadelerden hangisi doğrudur?

a)Ventrogluteal bölge zorunlu olmadıkça kullanılmamalıdır.
b)Gluteus maksimus kası bebekler 7 aylık oluncaya kadar kullanılmamalıdır.

c)Dorsogluteal bölgenin kullanılması siyatik sinir zedelenme riskini azaltmaktadır.

d) İğnenin dokuya giriş açısı her zaman $90^{\circ}$ dir

e)Yetişkinlerde deltoid bölgeye verilebilecek maksimum ilaç miktarı 2,5 ml" dir

5. Hemşire intramüsküler enjeksiyon yaparken enjektöre kan gelirse ne yapmalidir?

a)Enjektörü çıkarmalı ve yeni bir iğne takmalı

b) Enjektör atılmalı ve yeni bir enjeksiyon hazırlanmalı

c)İşlem durdurulmalı ve doktora bildirilmeli

d)Enjektör hafifçe geri çekilmeli ve çözelti enjekte edilmeli

e) Enjeksiyona devam edilmeli

\section{SONUÇ VE ÖNERILER}

İntramüsküler enjeksiyon konusunda geliştirilen bu başarı testi, hemşirelik öğrencilerine uygulanabilir, geçerli bir ölçektir. Testin hazırlanması aşamasında bazı ön çalışmaların yapılması eksikliklerin ortaya çıkmasını ve öğrencilerin testi cevaplaması için gerekli sürenin tespit edilmesini sağlamıştır. Öğrencilerin IM enjeksiyona ilişkin sahip oldukları bilgi ve bu konudaki eksikleri belirlenmesini sağlayarak eğitmen ve öğrencilere gelecek eğitim planlamaları açısından firsat tanımaktadır. İntramüsküler enjeksiyon başarı testi 21 soru maddesinden oluşmuştur. Testin ortalama güçlüğü 0,59 , KR-20 güvenirlik katsayısı ise 0,71 olarak hesaplanmıștır. Elde edilen veriler doğrultusunda hazırladığımız başarı testi geçerli ve güvenilir bir testtir.

Geliştirilmiş olan bu başarı testi ile ilgili geçerlik ve güvenirlik çalışmalarından elde edilen bulguların çerçevesinde eğitimde daha etkin kullanılabilmesi için bazı önerilerde bulunulabilinir. Yapılacak çalışmalarda örneklem sayısını fazla tutmak ve öğrencileri farklı eğitim-öğretim kurumlarından seçmek çalışmayı daha da kuvvetlendirecektir. Ayrıca geliştirilen bu başarı testinin kullanılacağı araştırmaların yapılması ölçme gücüne önemli katkılar sağlayacaktır.

KAYNAKLAR

1. Ferguson, A, Delaney, B, Hardy, G. (2014). "Teaching Medication Administration Through Inovative Simulation." Teaching and Learning in Nursing, 9, 64-68.

2. Meechan, R, Jones, H, Valler-Jones, T. (2011). "Do Medicines OSCES Iprove Drug Administration Ability?" British Journal of Nursing, 20 (13), 817-822.
3. Cirp1, F, Merih, Y.D, Kocabey, MY. (2009). "Hasta Güvenliğine Yönelik Hemşirelik Uygulamalarının ve Hemşirelerin $\mathrm{Bu}$ Konudaki Görüşlerinin Belirlenmesi.' Maltepe Üniversitesi Hemşirelik Bilim ve Sanatı Dergisi, 2, 2634.

4. Hemşirelik Yönetmeliği. (2010). Resmi Gazete, 27515 8.3.2010. 
5. Malkin, B. (2008). "Are Techniques Used for Itramuscular Injection Based on Research Evidence?" Nursing Times, 104, $48-51$

6. Kara, D, Uzelli, D, Karaman, D. (2015). "Using Ventroglutea Site in Itramuscular Injections is a Priority or an Alternative?" Internation Journal Of Caring Sciences, 8 (2), 507.

7. Nicoll, L.H, Hesby, A. (2002). "Intramuscular Injection: an Integrative Research Review and Guideline for Evidence-Based Practice.” Applied Nursing Research, 16 (2),149-162.

8. Greenway, K. (2004). "Using The Ventrogluteal Site for Intramuscular Injection.” Nursing Standard, 18 (25), 39-42.

9. Perry, A.G, Potter, P.A, Ostendorf, W.R. (2014). Clinical Nursing Skills and Techniques (8. Edition). St. Louis: Mosby.

10. Floyd, S, Meyer, A. (2007). "Intramuscular Injections-What's Best Practice?" Nursing New Zealand, 13 (6), 20-22.

11. Cocoman, A, Murray, J. (2010). "Recognizing the Evidence and Changing Practice on Ijection Site." British Journal of Nursing, 19 (18), 1170-1174.

12. Gülnar, E, Çalışkan, N. (2014). "Hemşîrelerin Ventrogluteal Bölgeye İntramüsküler Enjeksiyon Uygulamasına Yönelik Bilgi Düzeylerinin Belirlenmesi.” Dokuz Eylül Üniversitesi Hemşirelik Yüksekokulu Elektronik Dergisi, 7 (2), 70-77.

13. Tuğrul, E, Denat, Y. (2014). "Hemșirelerin Ventrogluteal Alana Enjeksiyon Uygulamaya İlişkin Bilgi, Görüş ve Uygulamaları.’ Dokuz Eylül Üniversitesi Hemşirelik Yüksekokulu Elektronik Dergisi, 7 (4), 275-284.

14. Gülnar, E, Özveren, H. (2016). "An Evaluation of The Effectiveness of a Planned Training Program for Nurses on Administering Intramuscular Injections into The Ventrogluteal Site." Nurse Education Today, 36, 360-363.

15. Demir, N, Kızılay, E, Bektaș, O. (2016). "7. Sınıf Çözeltiler Konusunda Başarı Testi Geliştirme: Geçerlilik ve Güvenirlik Çalışması." Necatibey Eğitim Fakültesi Elektronik Fen ve Matematik Eğitimi Dergisi, 10 (1), 209-237.

16. Can Şen, H, Eryılmaz, A. (2011). "Bir Başarı Testi Geliştirme Calıșması: Basit Elektrik Devreleri Başarı Testi Geçerlilik ve Güvenirlik Araştırması.” Yüzüncü Yı1 Eğitim Fakültesi Dergisi, $8(1), 1-39$
17. Gönen, S, Kocakaya, S, Kocakaya, F. (2011). "Dinamik Konusunda Geçerliği ve Güvenirliği Sağlanmış Bir Başarı Testi Geliștirme Çalıșması.” Yüzüncü Yıl Eğitim Fakültesi Dergisi, 8 (1), 40-57.

18. Akbulut, H. İ, Çepni, S. (2013). "Bir Üniteye Yönelik Başarı Testi Nasıl Geliştirilir?: Ilköğretim 7. Sınıf Kuvvet ve Hareket Ünitesi.” Amasya Üniversitesi Eğitim Fakültesi Dergisi, 2 (1), 18-44.

19. Calık, M, Ayas, A. (2003). "Çözeltilerde Kavram Başarı Test Hazırlama ve Uygulama." Pamukkale Üniversitesi Eğitim Fakültesi Dergisi, 2 (14), 1-17.

20. Atabek Aşt1, T, Karadağ, A. (2011) Klinik Uygulama Becerileri ve Yöntemleri. Adana: Nobel Kitabevi.

21. Lynn, P. (2011) Taylor's Clinical Nursing Skills, Lippincott Williams and Wilkins, 3.Edition.

22. Turgut, M. F, Baykul, Y. (2010). Eğitimde Ölçme ve Değerlendirme. Ankara: PegemA Yayıncılık.

23. Özçelik, D. A. (2010). Test Hazırlama Kılavuzu. Ankara: PegemA Yayıncilık.

24. Atılgan, H, Doğan, N, Kan, A. (2006). Eğitimde Ölçme ve Değerlendirme (Ed.Hakan Atılgan). Ankara: Anı Yayıncılık

25. Yılmaz, H. (2012). Eğitimde Ölçme ve Değerlendirme. Ankara: Cizgi Kitabevi.

26. Çepni, S, Bayrakçeken, S, Yılmaz, A, Yücel, C, Semerci, Ç, Köse, E, Sezgin, F, Demircioğlu, G ve Gündoğdu, K. (2008). Ölçme ve Değerlendirme. Ankara: Pegem Akademi.

27. Bademci, V. (2006). "Tartışmayı Sonlandırmak: Cronbach'ın Alfa Katsayısı, İki Değerli $(0,1)$ Ölçümlenmiş Maddeler ile Kullanılabilir.” Kazım Karabekir Eğitim Fakültesi Dergisi, 13, 438-446.

28. Çakır, M, Aldemir, B. (2011). "İki Așamalı Genetik Kavramlar Tanı Testi Geliştirme ve Geçerlilik Çalışması.” Mustafa Kemal Üniversitesi Sosyal Bilimler Enstitüsü Dergisi, 8 (16), 335-353.

29. Pilten, P. (2008). "Matematiksel Muhakemeyi Değerlendirme Ölçeği: Ölçek Geliştirme, Güvenirlik ve Geçerlilik Çalışması." Selçuk Üniversitesi Ahmet Keleşoğlu Eğitim Fakültesi Dergisi, 25, 297-316 